\title{
Ichthyofauna on three seamounts off southern and central California, USA
}

\author{
Lonny Lundsten ${ }^{1, *}$, Craig R. McClain ${ }^{1,2}$, James P. Barry ${ }^{1}$, Gregor M. Cailliet ${ }^{3}$, \\ David A. Clague ${ }^{1}$, Andrew P. DeVogelaere ${ }^{4}$ \\ ${ }^{1}$ Monterey Bay Aquarium Research Institute, 7700 Sandholdt Road, Moss Landing, California 95039-9644, USA \\ ${ }^{2}$ National Evolutionary Synthesis Center, Duke University, 2024 West Main Street, Durham, North Carolina 27707, USA \\ ${ }^{3}$ Moss Landing Marine Laboratories, Moss Landing, California 95039, USA \\ ${ }^{3}$ Monterey Bay National Marine Sanctuary, 299 Foam Street, Monterey, California 93940, USA
}

\begin{abstract}
In many regions of the world, commercial fisheries for seamount-aggregating species have collapsed. Most are trawl fisheries, which have been implicated in the destruction and loss of fragile coral and sponge habitat and potentially endemic seamount species. Even with the intense fishing effort over seamounts, our understanding of processes regulating the distribution and abundance of seamount fish assemblages, which is vital to conservation policy, is weak. Here, we describe the abundance and distribution of demersal fishes found on 3 seamounts off central and southern California. Video observations were taken during 27 dives of a remotely operated vehicle (ROV), and were annotated in detail using the Monterey Bay Aquarium Research Institute's (MBARI) Video Annotation Reference System (VARS). Video analysis yielded 2151 observations of 36 identified taxa. No aggregations of fishes were observed during the surveys. Video transects were analyzed to quantify organism density. Similarity among seamounts was compared using Bray-Curtis similarity estimates. Our results indicate high similarity among seamount faunas at similar depths, a shift from provincial to abyssal/cosmopolitan species with increased depth, and no evidence of seamount endemism.
\end{abstract}

KEY WORDS: Seamount fishes - Seamount biology · California seamounts - Deep sea fishes · Seamount ecology · Deep sea ecology

Resale or republication not permitted without written consent of the publisher

\section{INTRODUCTION}

Previously productive commercial fisheries for seamount-aggregating fish species like orange roughy, alfonsinos, armorheads, and oreos have collapsed in many regions of the world, and trawl-based fishing practices employed by fishers have been implicated in the destruction of fragile benthos (Probert et al. 1997, Koslow et al. 2001, Fosså et al. 2002, Clark et al. 2006, Fry et al. 2006). These fisheries are described as being more similar to 'mining' than to sustainable fisheries and are characterized by successive rapid development and declines sustained only by finding new, unexploited stocks (Koslow et al. 2000, Watson \& Morato 2004). Among deep-sea fisheries, $64 \%$ of seamountonly fisheries have collapsed vs. 46 to $49 \%$ for non- seamount and mixed seamount fisheries (Watson \& Morato 2004). Because of these issues, many scientists, non-governmental agencies, and governments advocate trawl regulations and the establishment of marine reserves in an effort to preserve or restore troubled fish populations.

Vital to establishing management and policy guidelines is the knowledge of biogeographic patterns and baseline assessments of seamount fish assemblages. Adding to the difficulties in understanding and managing these fisheries, seamount fish faunas are thought to possess a variety of characteristics, many of which being contradictory, including high genetic diversity (Froese \& Sampang 2004), high rates of endemism (Wilson \& Kaufmann 1987, Richer de Forges et al. 2000, Koslow et al. 2001), and similarity to regional 
(Wilson \& Kaufmann 1987, Tracey et al. 2004, Hoff \& Stevens 2005) or cosmopolitan (Wilson \& Kaufmann 1987) faunas. Koslow (1997) demonstrated that seamount-aggregating fishes differ from background deep-sea fishes in both lifestyle and metabolism, suggesting that seamount fish faunas are in fact unique. These faunas, like other deep-sea fishes, are often composed of long-lived species with slow rates of reproduction and are, therefore, vulnerable to overfishing (Koslow 1997, Koslow et al. 2000, Koslow et al. 2001, Froese \& Sampang 2004, McClatchie \& Coombs 2005). Seamounts are hypothesized to be able to support unique faunas for various reasons, including concentration of food and increased productivity (Genin et al. 1988, Rogers 1994). Of seamount fishes globally, macrourids, scorpaenids, morids, squalids, alepocephalids, and serranids are reported to be the most diverse families (Wilson \& Kaufmann 1987), while scorpaenids, morids, serranids, macrourids, and squalids are the most abundant. Wilson \& Kaufmann (1987) estimated that $11.6 \%$ of seamount fishes are endemic to seamounts, but also stated that most reports of endemism appear to be overestimated because of poorly known species distributions. This is supported by the increase in the known range of many species, including invertebrates, subsequent to their initial description (Tracey et al. 2004, Hall-Spencer et al. 2007, McClain 2007, O'Hara 2007, Lundsten et al. 2009, McClain et al. 2009).

More recent studies suggest that seamount fish faunas are not unique to seamounts but are, in fact, similar to the fauna inhabiting the surrounding region (Tracey et al. 2004, Hoff \& Stevens 2005). Tracey et al. (2004) found that species richness was consistently higher on flat slopes off New Zealand than on seamounts, noting that the orange roughy fishery was initially developed on flat slopes, and that seamount fisheries were developed in concert with improved technology and knowledge of seamountaggregating behavior. They also reported that fishes on New Zealand seamounts are typically not obligate seamount dwellers but are found widely throughout the region in habitats with suitable physical factors. Similar results were found at Patton Seamount in the Gulf of Alaska (Hoff \& Stevens 2005).
In this paper, we describe the ichthyofauna at 3 northeast Pacific seamounts (Fig. 1) by examining composition, biogeography, and horizontal and vertical faunal turnover. Ichthyofaunal patterns derived from this study may represent the fish assemblages typical of seamounts in proximity to a continental margin.

\section{MATERIALS AND METHODS}

We sampled 3 seamount communities at Davidson (D), Pioneer (P), and Rodriguez (R) using MBARI's remotely operated vehicle (ROV) 'Tiburon', including video observations recorded using high-resolution video equipment. The composition of the seamount ichthyofauna was determined from an analysis of $191 \mathrm{~h}$

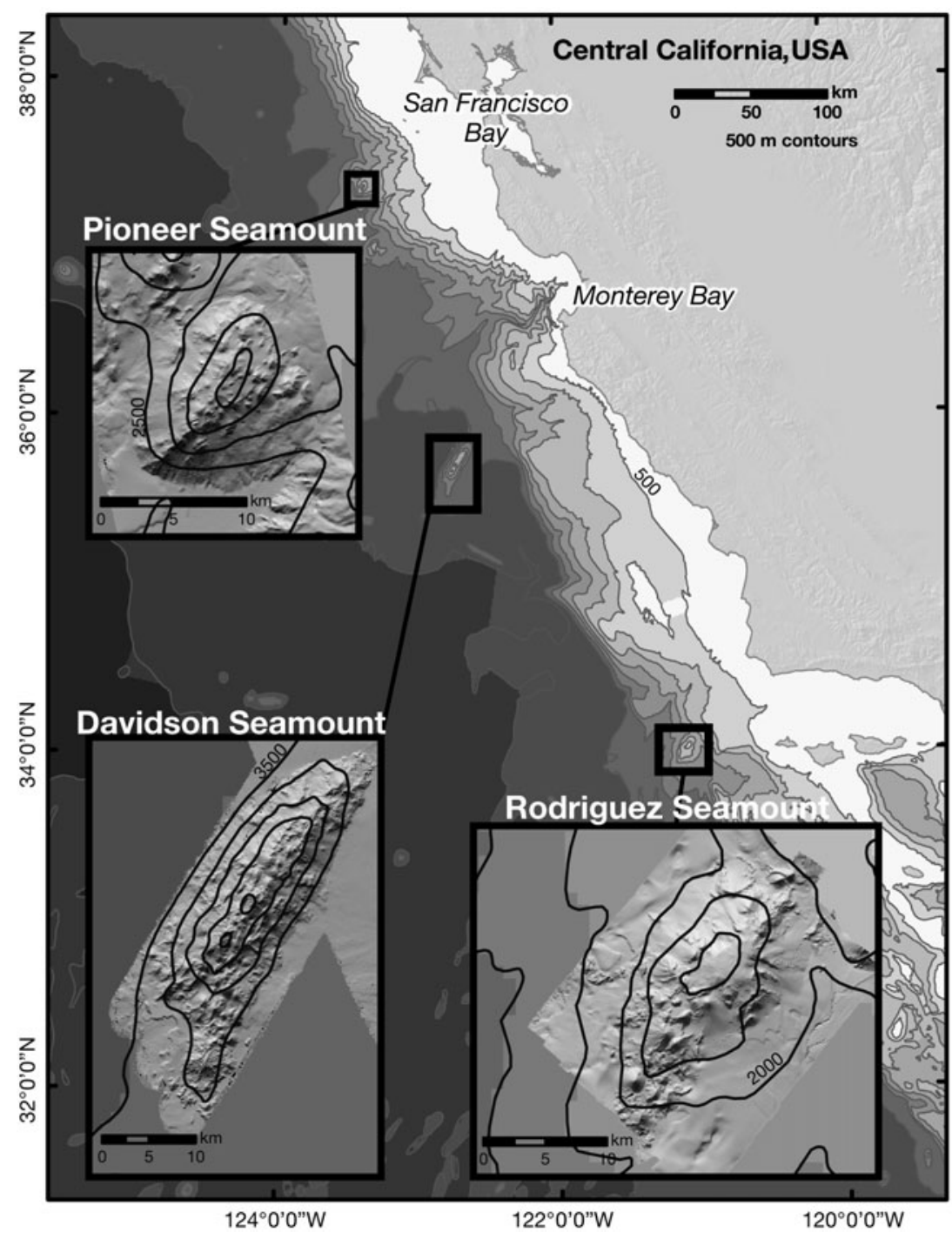

Fig. 1. Location of Davidson, Pioneer, and Rodriguez Seamounts off Central California, USA (from Lundsten et al. 2009) 
Table 1. Seamount dimensions, distance from shore, and depths sampled

\begin{tabular}{|lccccccc|}
\hline Seamount & $\begin{array}{c}\text { Length } \\
(\mathrm{km})\end{array}$ & $\begin{array}{c}\text { Width } \\
(\mathrm{km})\end{array}$ & $\begin{array}{c}\text { Base } \\
\text { depth }(\mathrm{m})\end{array}$ & $\begin{array}{c}\text { Summit } \\
\text { depth }(\mathrm{m})\end{array}$ & $\begin{array}{c}\text { Depths } \\
\text { sampled }(\mathrm{m})\end{array}$ & $\begin{array}{c}\text { Proportion of total } \\
\text { depths sampled }(\%)\end{array}$ & $\begin{array}{c}\text { Distance } \\
\text { from shore }(\mathrm{km})\end{array}$ \\
\hline Davidson & $\sim 42.0$ & $\sim 13.5$ & 3656 & 1246 & $1256-3289$ & 90 & $\sim 90$ \\
Pioneer & $\sim 12.8$ & $\sim 12.8$ & 2750 & 811 & $811-1815$ & 66 & $\sim 80$ \\
Rodriguez & $\sim 12.8$ & $\sim 12.8$ & 2325 & 619 & $619-2120$ & 91 & $\sim 60$ \\
\hline
\end{tabular}

of video drawn from 27 dives on the 3 seamounts. These video recordings were annotated in detail by trained video analysts using MBARI's Video Annotation and Reference System, VARS (Schlining \& Stout 2006). Fish identifications were made by the first author with assistance from the other authors. Taxonomic experts were consulted when necessary and include D. Didier, R. N. Lea, and D. A. Ebert. Estimates of biogeographic distributions and endemicity were based on VARS, Fishbase, and the knowledge of taxonomic experts.

Video data were collected from various depths at each seamount (Table 1). Davidson Seamount was sampled from its summit at $1246 \mathrm{~m}$ to a depth of $3289 \mathrm{~m}$ (90\% of seamount depth range sampled). Pioneer Seamount was sampled from its summit at $811 \mathrm{~m}$ to a depth of $1815 \mathrm{~m}$ ( $66 \%$ of seamount depth range sampled). Rodriguez Seamount was sampled from its summit at $619 \mathrm{~m}$ to a depth of $2120 \mathrm{~m}$ (91\% of seamount depth range sampled).

Plots of cumulative species richness vs. total distance traversed by the ROV were used to evaluate adequacy of sampling for seamount fishes. Curves were calculated using the Mao Tao function in EstimateS version 8.0 (Colwell 2005) and plotted for each seamount using $1 \mathrm{~km}$ bins of the total distance traversed and species presence/absence data within those bins.

Quantitative video transects (40) collected at Davidson Seamount in 2006 and Pioneer Seamount in 2007 were used to estimate fish density (no. $\mathrm{m}^{-2}$ ). Thirtythree transects were collected between 1298 and $3276 \mathrm{~m}$ depth at Davidson Seamount; these transects varied in length (45 to $445 \mathrm{~m}$ ) and width (0.97 to $8.17 \mathrm{~m})$. Seven transects were collected between 844 and $1240 \mathrm{~m}$ at Pioneer Seamount; these transects varied in length (66.8 to $261.6 \mathrm{~m}$ ) and width (1.57 to $2.62 \mathrm{~m}$ ). Two $640 \mathrm{~nm}$ red lasers placed $29 \mathrm{~cm}$ apart were used to estimate transect width. Transect length was calculated in ArcView 3.2 using the Animal Movement Analysis Extension version 2, which was used to calculate successive distance between transect start and end points (Hooge \& Eichenlaub 1997).

Bathymetric variation in fish abundance at the family level was compared among seamounts. The abundance of fishes observed over all dives on each seamount were summed within families for each $50 \mathrm{~m}$ depth bin, and normalized by the total ROV transit time within each depth.

Bray-Curtis similarity was calculated in PRIMER v6 (Clarke \& Gorley 2001) using 4th-root transformed densities of families observed per $500 \mathrm{~m}$ depth bins (samples). Non-metric multidimensional scaling (MDS) was used to explore turnover between depth bins and seamounts in a reduced multivariate space. Cluster analyses were done using group averages, based on the matrix of Bray-Curtis similarity indices comparing fish assemblages among pairs of transect locations. Using the RELATE function in PRIMER, we tested the correlation between the faunal similarity matrices and a model similarity matrix based solely on differences in depths between samples.

\section{RESULTS}

Smoothed cumulative taxa curves begin to approach an asymptote after an ROV transit length of $\sim 10$ to $15 \mathrm{~km}$ (Fig. 2). However, using the methods of Bizzarro et al. (2007) to quantitatively assess whether an asymptote was achieved for each taxon curve, we determined that an asymptote had not yet been achieved in terms of statistical significance. Nonetheless, the curves suggest that the ichthyofauna at each seamount is reasonably well characterized by our video analysis.

In total, 36 taxa representing 19 families were identified (Fig. 3, Table 2). Dominant fish families observed

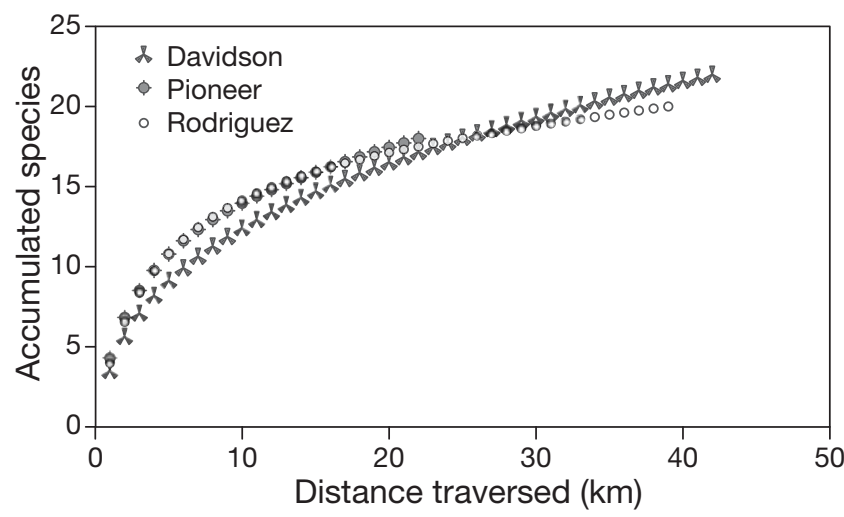

Fig. 2. Species accumulation curves (Mao Tao vs. traversed ROV distance) for fish taxa 


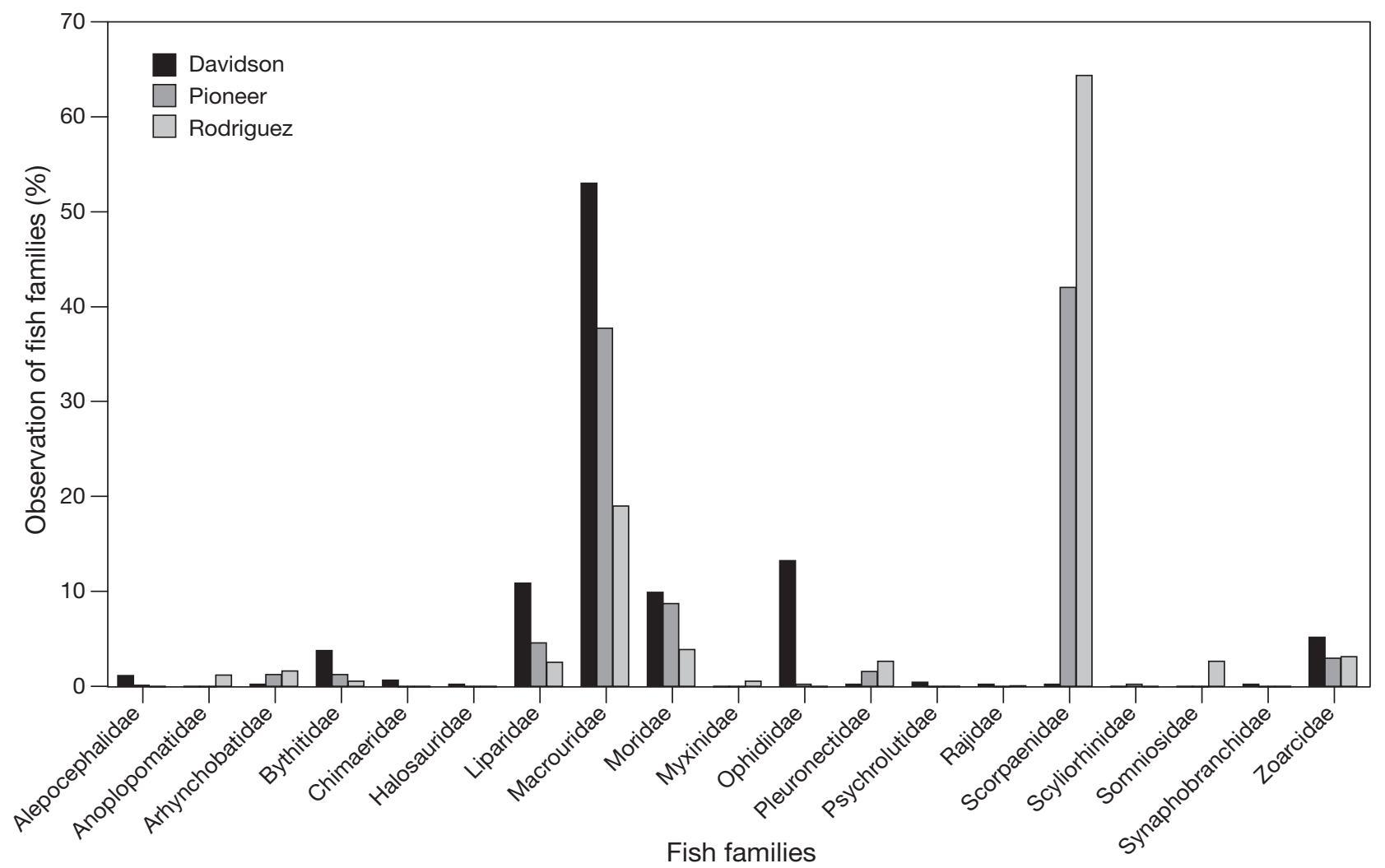

Fig. 3. Percent observation of fish families at Davidson, Pioneer, and Rodriguez Seamounts

included the Liparidae, Macrouridae, Moridae, Ophidiidae, Pleuronectidae, Scorpaenidae and Zoarcidae. Fishes representing other families were observed infrequently. Of these, only 1 taxon (Synaphobranchidae sp. 1) was not identifiable to species level by taxonomists consulted for this project. It is impossible to determine the range of this unidentified taxon as no specimens were collected. At Davidson Seamount, 22 taxa were identified and the dominant genera include Coryphaenoides (40.4\%), Spectrunculus (14.7\%), Antimora (10.24\%), and Careproctus (7.9\%). Of 18 fish taxa identified at Pioneer Seamount, Sebastolobus was the most common genus, accounting for $41.4 \%$ of all observations, followed by Coryphaenoides (18.9\%), and Antimora microlepis $8.8 \%$. Twenty taxa were identified at Rodriguez Seamount, dominated by $\mathrm{Se}$ bastolobus (64.2\%) and Coryphaenoides (13.5\%). Other important genera such as Antimora (3.9\%), Bothrocara (2.5\%) and Microstomus (2.5\%) were also observed (with lower ranking) at Rodriguez Seamount. A Pacific sleeper shark, Somniosus pacificus, was also observed at $1076 \mathrm{~m}$ during video analysis.

Quantitative video transects at Davidson and Pioneer Seamounts differed in mean organism density (Fig. 4). At Davidson Seamount, fish density averaged $0.0028 \pm 0.0006$ ind. $\mathrm{m}^{-2}$. At Pioneer Seamount, fish density averaged $0.025 \pm 0.0024$ ind. $\mathrm{m}^{-2}$. An overall decrease in fish density with depth was detectable but the trend may be related to differences between seamounts rather than to depth (Fig. 4).

Number of observations vs. depth distribution plots of fish families found to be common among the seamounts were similar for some families, like the Liparidae (Fig. 5). For other families, however, a shift in density occurred and was skewed towards shallower or deeper distributions. Pleuronectids and scorpaenids had shallow-skewed distributions, while bythitids, macrourids, ophidiids, and zoarcids were deep-skewed. In addition, many families that were represented by rare observations of single species occurred at greater depths, including Chimaeridae (2100 m), Halosauridae $(1900 \mathrm{~m})$, Psychrolutidae $(1250 \mathrm{~m})$ and Synaphobranchidae (2500 m).

The MDS plot of Bray-Curtis similarities between samples (Fig. 6a) displays clusters linked most strongly to depth and seamount. The 2 shallow samples at Pioneer (P1 \& P2) and Rodriguez (R1 \& R2) Seamounts cluster together, but these samples also cluster with a moderate depth sample from Davidson Seamount (D3). The deeper samples from Pioneer (P3) and Rodriguez Seamounts (R3 \& R4) also form a grouping that appears to be more closely related to the shallow-moderate depth grouping of Davidson Seamount samples (D2, D4, D5). The deepest sample from Davidson Sea- 


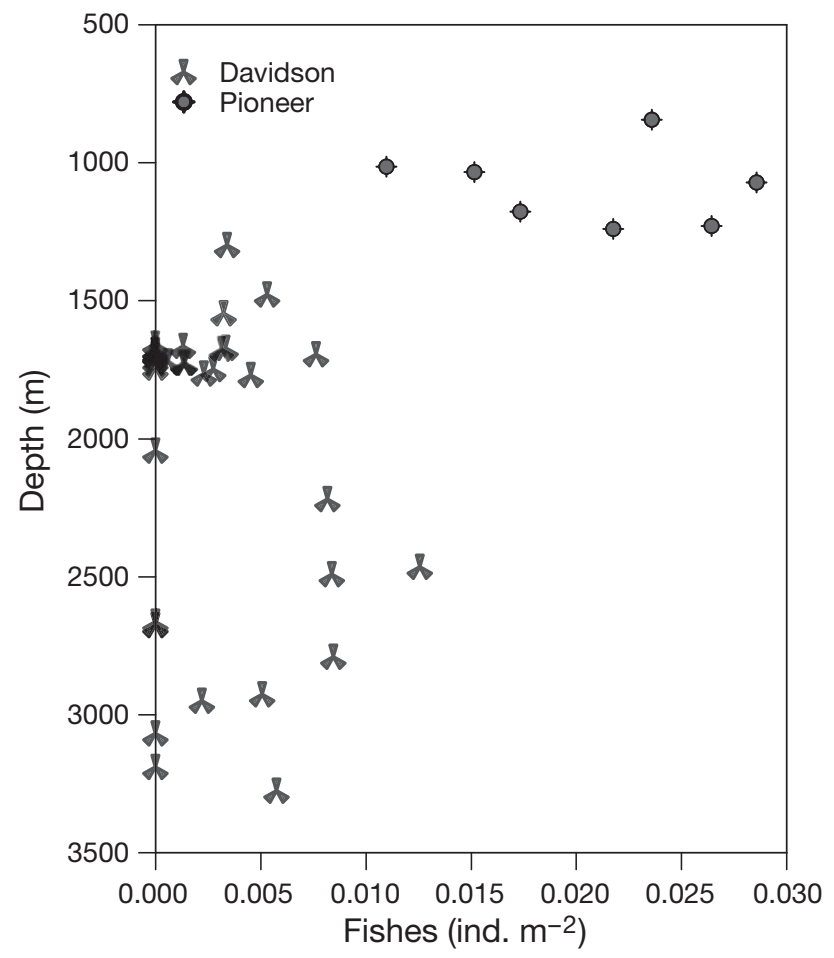

Fig. 4. Transect data showing fish density estimate by depth for transects collected at Davidson $(n=33)$ and Pioneer $(n=7)$ Seamounts. Fish density averaged $0.0028 \pm 0.0006$ ind. $\mathrm{m}^{-2}$ at Davidson Seamount and $0.025 \pm 0.0024$ ind. $\mathrm{m}^{-2}$ at Pioneer Seamount

mount, D6, forms its own grouping, as expected, since samples from this depth were not observed at the other 2 seamounts. A model matrix based on differences between samples that were related solely to depth (Fig. 6b) is significantly correlated $(\rho=0.683, p=0.001$ ) with our sample similarity matrix and indicates that the faunas are significantly bathymetrically zoned. A cluster analysis of the data (Fig. 6c) indicates 4 major groups, including the Davidson deep (D6), Davidson shallow-moderate (D2, D4, D5), Pioneer and Rodriguez shallow (P1, P2, R1, R2, D3), and Pioneer and Rodriguez moderate/deep (P3, R3, R4) groups.

\section{DISCUSSION}

Seamounts along the California continental margin have complex and diverse fish assemblages, which show little evidence of endemicity and are organized mainly by depth and other bathymetric or topographic features unique to each seamount. Although fish density differed between seamounts where quantitative transects were collected (D, P), it is unclear what factors are responsible for this pattern. Potential explanations include under-sampling, variation in food availability between sites and depths, or other processes
Table 2. Taxa identified at Davidson (D), Pioneer (P), and Rodriguez (R) Seamounts, with percentages for 8 dominant fish families (bold) shown

\begin{tabular}{|c|c|c|c|c|}
\hline \multirow{2}{*}{ Taxon } & \multirow{2}{*}{ Family } & \multicolumn{3}{|c|}{ Seamount $(\%)$} \\
\hline & & $\mathrm{D}$ & $\mathrm{P}$ & $\mathrm{R}$ \\
\hline $\begin{array}{l}\text { Alepocephalus tenebrosus } \\
\text { Alepocephalidae sp. } 1\end{array}$ & Alepocephalidae & & & \\
\hline Anoplopoma fimbria & Anoplopomatidae & & & \\
\hline $\begin{array}{l}\text { Bathyraja abyssicola } \\
\text { Bathyraja trachura }\end{array}$ & Arhynchobatidae & & & \\
\hline Cataetyx sp. & Bythitidae & 3.8 & 1.3 & 0.6 \\
\hline Hydrolagus trolli & Chimaeridae & & & \\
\hline Aldrovandia sp. & Halosauridae & & & \\
\hline $\begin{array}{l}\text { Careproctus microstomus } \\
\text { Careproctus ovigerum } \\
\text { Liparidae sp. } 1 \text { (Black head) }\end{array}$ & Liparidae & 11.5 & 4.6 & 2.6 \\
\hline $\begin{array}{l}\text { Albatrossia pectoralis } \\
\text { Coryphaenoides acrolepis } \\
\text { Coryphaenoides armatus } \\
\text { Coryphaenoides cinereus } \\
\text { Coryphaenoides leptolepis }\end{array}$ & Macrouridae & 53.1 & 37.8 & 19.1 \\
\hline Antimora microlepis & Moridae & 10.2 & 8.8 & 3.9 \\
\hline Eptatretus stoutii & Myxinidae & & & \\
\hline $\begin{array}{l}\text { Luciobrotula sp. } \\
\text { Spectrunculus grandis }\end{array}$ & Ophidiidae & 14.7 & 0.3 & 0.0 \\
\hline $\begin{array}{l}\text { Glyptocephalus zachirus } \\
\text { Microstomus bathybius } \\
\text { Pleuronichthys coenosus }\end{array}$ & Pleuronectidae & 0.3 & 1.6 & 2.7 \\
\hline Psychrolutes phrictus & Psychrolutidae & & & \\
\hline $\begin{array}{l}\text { Amblyraja badia } \\
\text { Raja sp. }\end{array}$ & Rajidae & & & \\
\hline $\begin{array}{l}\text { Sebastes sp. } \\
\text { Sebastolobus sp. }\end{array}$ & Scorpaenidae & 0.3 & 42.1 & 64.4 \\
\hline $\begin{array}{l}\text { Apristurus kampae } \\
\text { Scyliorhinidae sp. }\end{array}$ & Scyliorhinidae & & & \\
\hline Somniosus pacificus & Somniosidae & & & \\
\hline Synaphobranchidae sp. 1 & Synaphobranchidae & & & \\
\hline $\begin{array}{l}\text { Bothrocara brunneum } \\
\text { Lycenchelys sp. } \\
\text { Pachycara bulbiceps } \\
\text { Zoarcidae sp. }\end{array}$ & Zoarcidae & 5.2 & 3.0 & 3.2 \\
\hline
\end{tabular}

(Carney 2005, Rex et al. 2006). Estimates of fish density on Pioneer Seamount were similar to those found at comparable depths in this region (Cailliet et al. 1999), but densities on Davidson Seamount were lower than expected.

Species composition change in relation to depth was high for the entire fish assemblage. This high species turnover appears to be related to a mixture of overlapping, but variable, depth ranges among species. Only 2 of the fish species identified were not previously known from the continental slope or abyssal plain off California, and the dominant fish families reported here are consistent with other studies of deep-sea fish fauna off central California (Cailliet et al. 1999). 

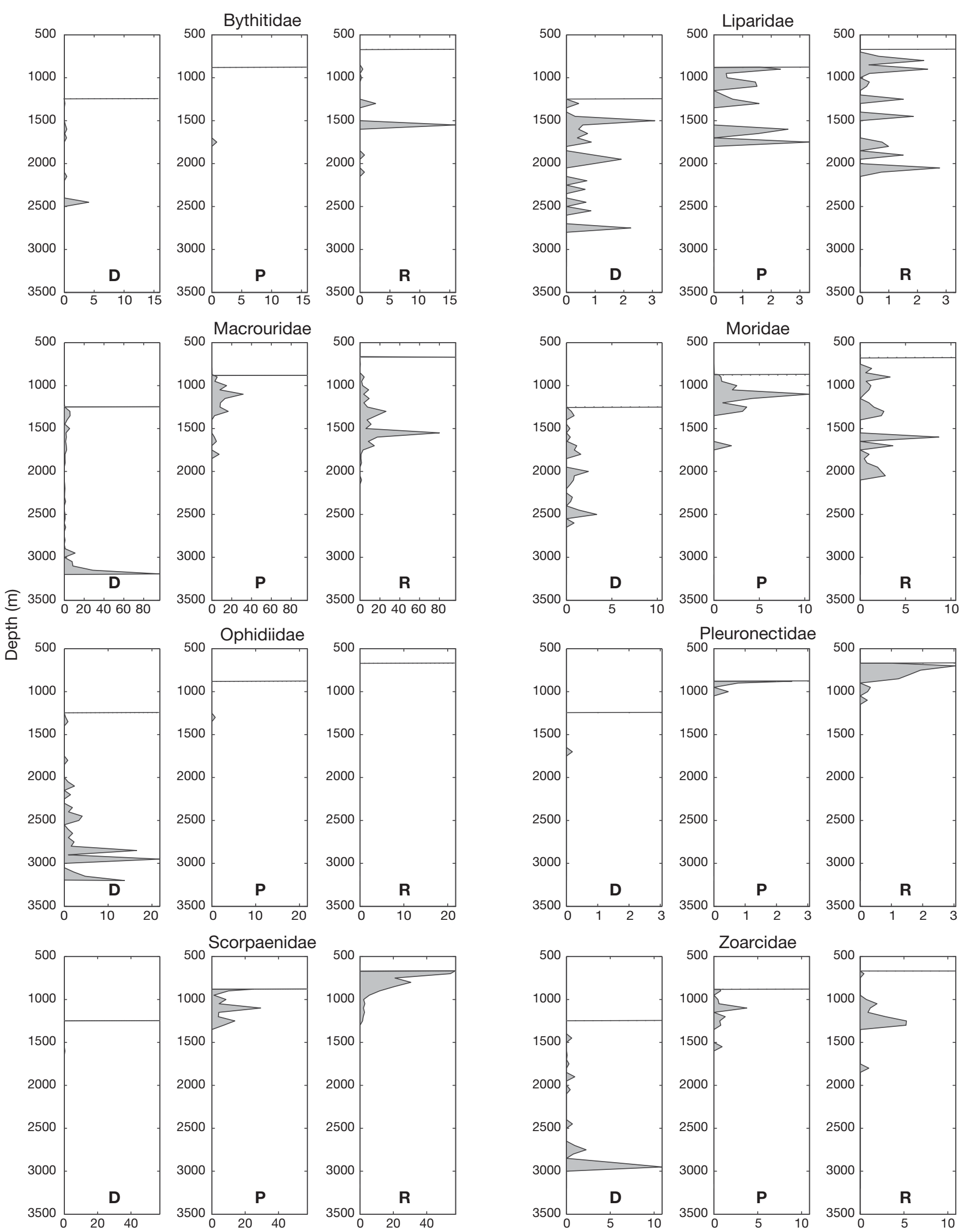

No. of fishes observed

Fig. 5. Number of fishes observed over all dives on each seamount summed within families for each $50 \mathrm{~m}$ depth bin, and normalized by the total ROV transit time within each depth. Data are plotted vs. depth for each of the dominant fish families at Davidson

(D), Pioneer (P), and Rodriguez (R) Seamounts. Horizontal lines represent seamount summit 

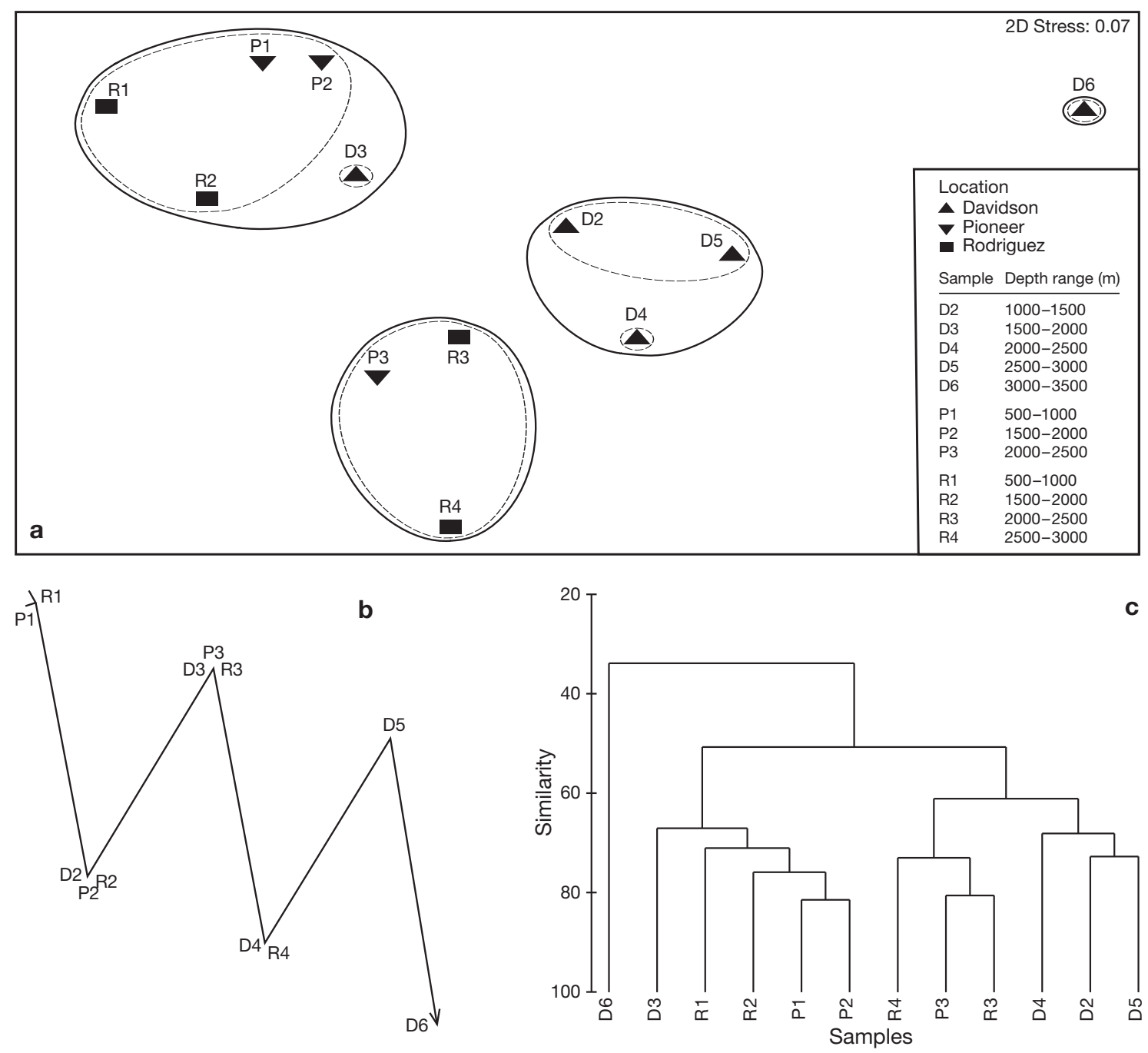

Fig. 6. Bray-Curtis similarities of 4th-root transformed density data at the family level in $500 \mathrm{~m}$ depth bins calculated for each seamount (Davidson [D], Pioneer [P] and Rodriguez [R]). (a) Non-metric multidimensional scaling (MDS) plot of the data; solid grouping lines represent $62 \%$ similarity, dashed grouping lines represent $70 \%$ similarity. (b) Model matrix of similarities, based on depth differences; empirical and model matrix are significantly correlated $(\rho=0.683, p=0.001)$. (c) Cluster analysis of the data

Our results show low or no endemicity for the fish assemblage at the 3 seamounts studied. Several fishes known from the California abyssal plain were observed only at Davidson Seamount. These fishes include Aldrovandia sp. ( $\mathrm{n}=1)$, Pachycara bulbiceps $(\mathrm{n}=9)$, Psychrolutes phrictus $(\mathrm{n}=2)$, and Spectrunculus grandis $(\mathrm{n}=56)$. Other rare fish species that were observed only at Davidson Seamount and not known previously along this coast include Hydrolagus trolli $(\mathrm{n}=3)$, which represents a range extension, and Synaphobranchidae sp. $1(\mathrm{n}=1)$, which may be a new species (although a physical specimen was not collected). Although these rare abyssal and cosmopolitan species were encountered, we found no evidence to suggest that these observations are indicative of a 'seamount fauna.' We think that they are simply rarely encoun- tered inhabitants of a large, under-sampled environment.

The high similarity among these 3 seamounts was likely related to their close proximity to each other and the similarity of depths surveyed. The divergence in similarity for fish community structure at Davidson Seamount is linked to its higher species richness. This may be related to depth, as most species unique to Davidson Seamount were observed along its deepest sampling stations (i.e. sample D6), at depths that have not been sampled at Pioneer or Rodriguez Seamounts. For some fish families, depth is certainly the factor limiting distribution. For example, we would not expect Scorpaenidae and Pleuronectidae to be observed in abundance at Davidson Seamount, as its summit is near the maximum depth of occurrence for these fami- 
lies off California (R. Lea pers. comm.). The dominant scorpaenid genus Sebastolobus observed during this survey consists of 2 species, both of which have even horizontal distribution and are $\mathrm{O}_{2}$ minimum zone (OMZ) specialists (Wakefield \& Smith 1990, Jacobson $\&$ Vetter 1996). Their occurrence in our surveys is consistent with information in the literature, as we found them in highest abundance within the OMZ, but never in large aggregations. Other species, like Psychrolutes phrictus, were observed on the summit of Davidson Seamount at depths comparable to those surveyed at Pioneer Seamount. At Rodriguez and Pioneer Seamounts, observations included more provincial, continental slope species, as expected based on Wilson \& Kaufmann (1987); they found that the fauna on shallow seamounts are represented by equal percentages of provincial and cosmopolitan species, while deep seamount faunas are dominated by cosmopolitan species. In general, Wilson \& Kaufmann (1987) theorized that provincial species decrease with depth relative to cosmopolitan species. The mechanisms behind this depth related shift from provincial to cosmopolitan species are not well understood, and Wilson \& Kaufmann (1987) did not address causal mechanisms directly, but noted several methods of organism dispersal onto seamounts that were developed by earlier workers, including stepping-stone dispersal, dispersal by currents, or active dispersal through swimming.

Depth appears to play the most significant role in structuring the fish communities at these seamounts. Because these communities rely nutritionally on the sinking flux of organic debris from the euphotic zone, which decreases by roughly $90 \%$ for each $\mathrm{km}$ of depth (Martin et al. 1987), it is not surprising that depth is an important factor related to faunal structure. Nutrient availability has been shown to limit organism density and biomass in the deep-sea (Rex et al. 2006), and this and other factors such as pressure, temperature, and detrital flux, which appear to be depth related, may also affect faunal turnover (Carney 2005). Our similarity analysis implies that depth is the most important control of faunal turnover, as most samples at similar depths tended to group together.

Differences in the fish assemblages among seamounts are related to depth of sampling, but may also be influenced by seamount shape, distance from shore, and proximity to the continental shelf (Wilson \& Kaufmann 1987). Davidson Seamount was dominated by deep-sea abyssal species of the Families Macrouridae, Ophidiidae, Liparidae, and Moridae, while fishes at Rodriguez Seamount were dominated by the Scorpaenidae genus Sebastolobus, which is a common northeastern Pacific continental slope genus. Pioneer Seamount was intermediate in depth and faunal composition. Rodriguez Seamount is closer to shore, is located on the continental slope, and has a relatively flat and shallow summit. Pioneer Seamount has a shallower summit than Davidson Seamount, but, like Davidson, it is a peaked seamount with its base at the foot of the continental slope. Wilson \& Kaufmann (1987) also noted that latitude and distance from shore may also influence the balance between provincial and cosmopolitan species; seamounts at higher latitudes and those closer to a continental slope may have more provincial species.

ROV surveys have been shown to cause both fish avoidance and attraction (Trenkel et al. 2004, Stein et al. 2005, Stein et al. 2006), which can add bias to reported results. The strength of avoidance or attraction often varies depending on species behavior and various physical parameters (Trenkel et al. 2004). As noted by Cailliet et al. (1999), various sampling schemes have both strengths and weaknesses. Avoidance by some fast moving fish species appears to be common among both trawl and submersible surveys.

Aggregations of fishes that could be commercially harvested were not observed at any of these seamounts, and evidence of previous trawling was observed only at Rodriguez Seamount during just 1 ROV dive (D. Clague unpubl. data). Davidson Seamount, which was recently added to The Monterey National Marine Sanctuary, appeared pristine (DeVogelaere et al. 2005, Lundsten et al. 2009) and its lack of anthropogenic disturbance makes this location particularly well suited to furthering our understanding of how nearshore seamounts function, which will aid policy makers in making management decisions. In addition, many of the species and genera found here are commercialy harvested off California, including the most abundant genera observed (Sebastolobus spp. and Coryphaenoides spp.) (Koslow et al. 2000).

\section{CONCLUSIONS}

The fish communities at Davidson, Pioneer, and Rodriguez Seamounts showed a high degree of similarity, with the majority of faunal turnover being related to depth, as predicted by others (e.g. Carney 2005). Endemism, a recent general postulate of seamount communities, was essentially absent in the fish communities at these 3 seamounts and, although all 3 are located in close proximity to each other and to the continental slope, we conclude that the seamount endemicity hypothesis (SMEH, McClain et al. 2009) cannot be broadly applied to all seamounts. Our results also support Wilson \& Kaufmann's (1987) hypothesis that shallower seamounts will typically have a more provincial fauna, compared to the more cosmopolitan assemblage expected for deep seamounts. Overall, the distri- 
bution, abundance, and natural history of fish assemblages inhabiting the seamounts studied here support the notion that these communities can be distinct from those of non-seamount habitats, especially the faunas of deeper seamounts, which may contain more rare abyssal and cosmopolitan species that make them highly vulnerable to the effects of bottom trawling and perhaps other anthropogenic disturbances.

Acknowledgements. We thank the pilots of the ROV 'Tiburon' and the crew of RV 'Western Flyer'; D. Didier, D. Ebert, and R. Lee for assistance with species identifications; and E. Lundsten, E. Burton, A. Andrews, and the anonymous referees who greatly improved this manuscript. This work was supported by the David and Lucile Packard Foundation through MBARI and NOAA's Office of Ocean Exploration.

\section{LITERATURE CITED}

Bizzarro JJ, Robinson HJ, Rinewalt CS, Ebert DA (2007) Comparative feeding ecology of four sympatric skate species off central California. Environ Biol Fishes 80:197-220

Cailliet GM, Andrews AH, Wakefield WW, Moreno G, Rhodes KL (1999) Fish faunal and habitat analyses using trawls, camera sleds and submersibles in benthic deep-sea habitats off central California. Oceanol Acta 22:579-592

Carney RS (2005) Zonation of deep biota on continental margins. Oceanogr Mar Biol Annu Rev 43:211-278

Clark MR, Tittensor D, Rogers AD, Brewin P and others (2006) Seamounts, deep-sea corals and fisheries: vulnerability of deep-sea corals to fishing on seamounts beyond areas of national jurisdiction. United Nations Environment Programme - World Conservation Monitoring Centre (UNEPWCMC), Cambridge

Clarke KR, Gorley RN (2001) PRIMER v6: user manual/ tutorial. PRIMER-E, Plymouth

Colwell RK (2005) EstimateS: statistical estimation of species richness and shared species from samples, version 7.5. User's guide and application. Available at http://viceroy. eeb.uconn.edu

DeVogelaere AP, Burton EJ, Trejo T, King CE and others (2005) Deep-sea corals and resource protection at the Davidson Seamount, California, USA. In: Freiwald A, Roberts JM (eds) Cold-water corals and ecosystems. SpringerVerlag, Berlin, p 1189-1198

Fosså JH, Mortensen PB, Furevik DM (2002) The deep-water coral Lophelia pertusa in Norwegian waters: distribution and fishery impacts. Hydrobiologia 471:1-12

Froese R, Sampang A (2004) Taxonomy and biology of seamount fishes. In: Morato T, Pauly D (eds) Seamounts: biodiversity and fisheries. 2004 Fisheries Centre Research Reports 12:25-32

Fry GC, Brewer DT, Venables WN (2006) Vulnerability of deepwater demersal fishes to commercial fishing: evidence from a study around a tropical volcanic seamount in Papua New Guinea. Fish Res 81:126-141

Genin A, Haury LR, Greenblatt P (1988) Interactions of migrating zooplankton with shallow topography: predation by rockfish and intensification of patchiness. DeepSea Res 35:151-175

Hall-Spencer JM, Rogers A, Davies J, Foggo A (2007) Historical deep-sea coral distribution on seamount, oceanic island and continental shelf-slope habitats in the NE Atlantic. In: George RY, Cairns SD (eds) Conservation and adaptive management of seamount and deep-sea coral ecosystems. Rosenstiel School of Marine and Atmospheric Science, University of Miami, FL, p 135-146

Hoff GR, Stevens B (2005) Faunal assemblage structure on the Patton Seamount (Gulf of Alaska, USA). Alsk Fish Res Bull 11:27-36

Hooge PN, Eichenlaub B (1997) Animal movement extension to ArcView, version 1.1. Alaska Science Center - Biological Science Office, US Geological Survey, Anchorage, AK

> Jacobson LD, Vetter RD (1996) Bathymetric demography and niche separation of thornyhead rockfish: Sebastolobus alascanus and Sebastolobus altivelis. Can J Fish Aquat Sci 53:600-609

Koslow JA (1997) Seamounts and the ecology of deep-sea fisheries. Am Sci 85:168-176

Koslow JA, Boehlert GW, Gordon JDM, Haedrich RL, Lorance P, Parin N (2000) Continental slope and deep-sea fisheries: implications for a fragile ecosystem. ICES J Mar Sci 57: 548-557

> Koslow JA, Gowlett-Holmes K, Lowry JK, O'Hara T, Poore GCB, Williams A (2001) Seamount benthic macrofauna off southern Tasmania: community structure and impacts of trawling. Mar Ecol Prog Ser 213:111-125

Lundsten L, Barry JP, Cailliet GM, Clague DA, DeVogelaere AP, Geller JB (2009) Benthic invertebrate communities on three seamounts off southern and central California, USA. Mar Ecol Prog Ser 374:23-32

> Martin JH, Knauer GA, Karl DM, Broenkow WW (1987) VERTEX: carbon cycling in the northeast Pacific. Deep-Sea Res 34:267-285

McClain CR (2007) Is seamount biogeography island biogeography? J Biogeogr 34:2001-2008

McClain CR, Lundsten L, Ream M, Barry JP, DeVogelaere AP (2009) Endemicity, biogeograhy, composition, and community structure on a northeast Pacific seamount. PLoS One 4:e4141

> McClatchie S, Coombs RF (2005) Spatial variability of orange roughy around the Northwest Hills on the Chatham Rise, New Zealand. Deep-Sea Res I 52:589-603

O'Hara TD (2007) Seamounts: centres of endemism or species richness for ophiuroids? Glob Ecol Biogeogr 16:720-732

Probert PK, McKnight DG, Grove SL (1997) Benthic invertebrate bycatch from a deep-water trawl fishery, Chatham Rise, New Zealand. Aquat Conserv: Mar Freshw Ecosyst $7: 27-40$

> Rex MA, Etter RJ, Morris JS, Crouse J and others (2006) Global bathymetric patterns of standing stock and body size in the deep-sea benthos. Mar Ecol Prog Ser 317:1-8

Richer de Forges B, Koslow JA, Poore GCB (2000) Diversity and endemism of the benthic seamount fauna in the southwest Pacific. Nature 405:944-947

Rogers AD (1994) The biology of seamounts. Adv Mar Biol 30:305-350

Schlining B, Stout NJ (2006) MBARI's video annotation and reference system. Proc Mar Technol Soc, Institute of Electrical and Electronics Engineers Oceans Conference. Oceans 18-21 Sept. 2006, p 1-5 Available at: http://ieeexplore. ieee.org/xpl/freeabs_all.jsp?arnumber $=4099034$

> Stein DL, Felley JD, Vecchione M (2005) ROV observations of benthic fishes in the Northwind and Canada Basins, Arctic Ocean. Polar Biol 28:232-237

> Stein DL, Drazen JC, Schlining KL, Barry JP, Kuhnz L (2006) Snailfishes of the central California coast: video, photographic and morphological observations. J Fish Biol 69: 970-986 
Tracey DM, Bull B, Clark MR, Mackay KA (2004) Fish species composition on seamounts and adjacent slope in New Zealand waters. N Z J Mar Freshw Res 38:163-182

Trenkel VM, Lorance P, Mahévas S (2004) Do visual transects provide true population density estimates for deepwater fish? ICES J Mar Sci 61:1050-1056

Wakefield WW, Smith KL Jr (1990) Ontogenetic vertical migration in Sebastolobus altivelis as a mechanism for transport of particulate organic matter at continental slope

Editorial responsibility: James McClintock, Birmingham, Alabama, USA depths. Limnol Oceanogr 35:1314-1328

Watson R, Morato T (2004) Exploitation patterns in seamount fisheries: a preliminary analysis. In: Morato T, Pauly D (eds) Seamounts: biodiversity and fisheries. 2004 Fisheries Centre Research Reports 12:61-66

Wilson RR, Kaufmann RS (1987) Seamount biota and biogeography. In: Keating BH, Fryer P, Batiza R, Boehlert GW (eds) Seamounts, islands, and atolls. Am Geophys Union Geophys Monogr 43:355-377

Submitted: January 26, 2009; Accepted: June 25, 2009 Proofs received from author(s): August 27, 2009 